\title{
ЭКСТРАТЕРРИТОРИАЛЬНОЕ ДЕЙСТВИЕ АКТОВ ГОСУДАРСТВА О НАЦИОНАЛИЗАЦИИ
}

В научной статье исследованы понятие, сущность, юридическая природа экстратерриториального действия актов государства о национализации имущества. Проанализированы международно-правовые акты, принятые международным сообществом по поводу национализации имущества, и практика признания таких действий государством, на территории которого проводится национализация иностранного имущества. С учетом зарубежного опыта и судебной практики признания экстратерриториального действия актов государства сделан вывод о необходимости систематизации и унификации правил проведения национализации.

Ключевые слова: национализация, экстратерриториальное действие актов государства, право собственности.

у науковій статmі досліджено поняття, сутність, юридичну природу екстратериторіальної дії актів держави щодо націоналізації майна. Проаналізовано міжнародно-правові акти, що ухвалені міжнародною спільнотою стосовно націоналізації майна, та практику визнання таких дій державою, на території якої має місце націоналізація іноземного майна. 3 урахуванням закордонного досвіду та судовоі практики визнання екстратериторіальної дії актів держави зроблено висновок про необхідність систематизаціі та уніфікації правил проведення націоналізації.

Ключові слова: націоналізація, екстратериторіальна дія актів держави, право власності.

Ashykhmin I. M. Extraterritorial operation of the state's acts on nationalization

The scientific article explores the concept, essence, legal nature of the extraterritorial effect of state acts on the nationalization of property. The international legal acts adopted by the international community regarding the nationalization of property and the practice of recognizing such actions by the state in whose territory the nationalization of foreign property is analyzed are analyzed. Taking into account foreign experience and judicial practice of recognizing the extraterritorial effect of state acts, it is concluded that there is a need to systematize and unify the rules for nationalization.

The author notes that the extraterritorial effect of state acts on nationalization also takes place at the present stage. Since the nationalization of property on the territory of a foreign state limits the right of a foreign state to state sovereignty and non-interference in internal affairs, there is a fine line between the alienation of such property on a legal basis and violation of the principles of international law, as well as national legislation of a foreign state. At the present stage of development of private international law, there are many approaches to determining the institution of recognition of the extraterritorial effect of acts of the state, but there are diametrically opposite points of view. It is necessary to develop such a mechanism of alienation of property in the territory of a foreign state (if necessary, and vice versa to protect against unscrupulous actions of the state conducting the nationalization) so that the rights of the owner, the state conducting the nationalization and the foreign state are respected and not violated.
Ашихмин И. М.

At the same time, it is necessary to take into account the varying practice of states in recognizing the extraterritorial effect of acts of a foreign state on the nationalization of property. In many respects, it depends on such factors as the legal culture of the state, diplomatic relations between two states (the degree of approval by the state of the actions of another state), national legislation and public policy of the state. The above indicates that the differing approaches to the recognition of a foreign state act on the nationalization of property located on its own territory depend on the will of the state.

Key words: nationalization, extraterritorial effect of state acts, property right.

Постановка проблемы и ее актуальность. Иностранные инвестиции и их допуск к национальной экономике государства-реципиента регулируются в соответствии с нормами национального законодательства и нормами международного права. Доктрина международного права признает право государства на национализацию иностранных инвестиций. В рамках деятельности Совета Организации европейского сотрудничества и развития (далее - ОЭСР) был разработан проект Конвенции о защите иностранной собственности, в котором было определено суверенное право государства на принудительное изъятие совокупности объектов иностранного инвестирования. В этом проекте были закреплены стандарт справедливого отношения, запрет неоправданных и дискриминационных мер, компенсация за экспроприацию, а также впервые стандарт защиты и безопасности. Хотя проект Конвенции о защите иностранной собственности ОЭСР 1967 г. так и не был принят, его положения стали моделью, которая применялась во многих двусторонних инвестиционных договорах [1, с. 114]. Резолюция 1803 (XVII) ГА ООН от 14 декабря 1962 г. «Неотъемлемый суверенитет над естественными ресурсами» признала право государства на национализацию иностранных инвестиций только при условии выплаты надлежащей компенсации [2]. Однако следует отметить, что условия проведения национализации объектов частной собственности устанавливаются не предписаниями международного права, а непосредственно законодательством государства, проводящего национализацию.

Целью статьи является попытка исследовать правовые вопросы экстратерриториального действия законов о национализации и условий их признания за границей.

Изложение основного материала. Говоря о национализации, необходимо понимать, что это акт изъятия частной собственности и передачи ее в государственную. Черты, присущие такому изъятию, схожи с экспроприацией. Самый главный вопрос, который необходимо решить иностранному инвестору и государству-реци- 
пиенту, - соблюдение законности и мотивированности таких действий. Следует исходить из того, что национализация - государственный акт, который имеет социально-экономическую направленность и проводится с целью предотвращения стагнации экономических показателей сектора, являющегося объектом инвестирования, в случае быстрой репатриации иностранных инвестиций. Поэтому правовое регулирование инвестиционной деятельности направлено на соблюдение условий, которые заключаются в осуществлении национализации (1) для достижения общественно полезной цели (2) на недискриминационной основе, (3) обязательной выплате компенсации и (4) на законных основаниях. Национальным законодательством государства-реципиента об осуществлении инвестиционной деятельности, как правило, предусмотрено возмещение физическим, юридическим лицам-нерезидентам за принудительное изъятие их собственности, а также проведение такого изъятия на конкретных условиях, в указанном порядке и определенный срок. Эти законы имеют экстратерриториальное действие, поэтому должны признаваться иностранным государством, поскольку имущество, которое подлежит национализации, может находиться за пределами территории государства, осуществляющего принудительное изъятие (например, имущество представительств, филиалов, обособленных подразделений, созданных юридическими лицами-резидентами в иностранных государствах).

В международном праве акты национализации порождают ряд теоретических и практических проблем, которые проявились прежде всего в двух аспектах: во-первых, акты национализации распространяются как на собственных граждан, так и на иностранцев; во-вторых, возникает вопрос о признании внутреннего акта государства другими странами, на территории которых может находиться национализируемый объект (так называемое экстратерриториальное действие закона о национализации). Что касается экстратерриториальности актов о национализации, особенно проблем выплаты компенсации, то эти вопросы не нашли однозначного ответа в доктринах международного публичного и международного частного права [3, с. 36]. Не получили они и единого разрешения в международной судебной практике.

Для соблюдения условий законности проведения национализации государствами должен соблюдаться принцип взаимности исполнения международных обязательств, а также избегания осуществления принудительного изъятия иностранных инвестиций. В случае проведения национализации необходимо проведение немедленной равноценной компенсации. Как правило, вопросы о проведении национализации заранее предусматриваются в соглашениях, которые заключаются между правительствами двух суверенных государств и именуются двусторонними международными соглашениями о защите и поощрении капиталовложений.

Вопросы, касающиеся регулирования и защиты права собственности иностранных физических и юридических лиц, международная практика и доктрина всегда относили к внутренней компетенции государств. Нормам международного права отводилась роль дополнительного регулятора, используемого в контексте прав, гарантируемых иностранцам, в частности, для защиты иностранных собственников от национализации, экс- проприации и других форм ограничения прав иностранной собственности. «Все, что предписывает международное право в этом плане, - пишет австрийский юрист А. Фердросс, - это то, что государство не должно произвольно нарушать частные права иностранцев» [3, с. 1].

В то же время не следует забывать, что право любого государства на национализацию частной собственности, в том числе и принадлежащую иностранным физическим и юридическим лицам, вытекает из такого общепризнанного принципа международного права, как суверенитет государства.

Условия проведения национализации определяются не международным правом, а внутренним правом государства, осуществляющего национализацию. Классический западный подход, нашедший свое отражение, в частности, в Руководстве по регулированию прямых иностранных инвестиций МБРР, которым признано право государства на осуществление экспроприации и национализации любой собственности, в том числе иностранной. В то же время необходимо соблюдение следующих условий: изъятие имущества должно осуществляться для достижения общественно полезных целей; на законных основаниях, то есть согласно юридически определенной и закрепленной в нормативном акте процедуре перехода права собственности от предыдущего собственника к государству; на недискриминационной основе; при условии быстрой, адекватной и эффективной компенсации.

Каждое государство в силу своего суверенитета имеет исключительное право на определение характера и содержания права собственности, установление порядка его приобретения, перехода или потери. Осуществление государством акта национализации также следует рассматривать как одну из форм проявления его суверенитета. Резолюция 626 ГА ООН от 1952 г. «О праве свободной эксплуатации естественных богатств и ресурсов» [4] утвердила право народов свободно распоряжаться своими естественными богатствами и ресурсами, а также свободно эксплуатировать их. В этой Резолюции предоставлена прямая рекомендация всем государствам-членам ООН воздерживаться от любого рода действий, направленных на ограничение суверенных прав любого государства в отношении его естественных богатств. Но, в противовес всему, Резолюцией 626 не закреплены положения, препятствующие государству осуществлять меры национализации иностранных инвестиций, самостоятельно определять условия проведения такой национализации.

В Декларации Генеральной Ассамблеи ООН от 1974 г. «Об установлении нового международного экономического порядка» [5] также было отмечено, что для охраны собственных ресурсов каждое государство имеет право осуществлять эффективный контроль над ними, включая право национализации или передачи владения своим гражданам, причем это право определено как наличие полного неотъемлемого суверенитета этого государства. Ни одно государство не может быть подвергнуто экономическому, политическому или любому другому виду принуждения с целью помешать свободному и полному осуществлению этого неотъемлемого права.

Признание права собственности государства на национализированное имущество, перемещаемое за границу, является необходимой предпосылкой осущест- 
вления международной торговли. Непризнание экстратерриториального действия акта о национализации подрывает международные экономические отношения.

Признание экстратерриториального действия нормативно-правовых актов о национализации следует из коллизионной привязки lex rei sitae, которая является ключевой при определении момента возникновения и перехода права собственности на имущество. Поэтому в случае возникновения соответствующих споров суды обязаны, по общему правилу, руководствоваться законодательством того государства, где была проведена национализация. Однако даже в случае повсеместного признания права собственности на вывезенное государством за границу национализированное имущество необходимо иметь в виду, что судебные органы некоторых государств имеют иное мнение относительно статуса национализированного имущества, находившегося в момент национализации за границей. Суды ссылаются при этом на то, что приобретение права собственности на имущество может определяться исключительно законами государства места его нахождения [6, с. 132].

Как уже было указано, в силу применяемых в каждой стране коллизионных норм моменты возникновения и перехода права собственности определяются по принципу lex rei sitae. Отсюда следует, что при рассмотрении иностранными судами вопросов, касающихся национализированного имущества, подлежат применению законы государства, осуществившего национализацию. С другой стороны, такая позиция не является бесспорной, в частности, некоторые ученые считают, что право собственности на имущество национализированного предприятия, находящееся за границей, должно определяться только по закону государства, где такое имущество находится, а не по праву государства, осуществившего национализацию.

Если право собственности на национализированное имущество, вывезенное за границу, получило повсеместное признание, то иное положение сложилось в судебной практике относительно национализированного имущества, находившегося в момент национализации за границей. Суды ссылаются при этом на то, что приобретение права собственности на имущество может определяться исключительно законами страны места его нахождения. Согласно коллизионной привязке lex societatis, правовой статус имущества национализированных предприятий с местонахождением за рубежом должен устанавливаться на основании норм законодательства иностранного государства, где находится такое имущество, нормами иностранного законодательства также определяется порядок ликвидации юридических лиц и правовые последствия, вытекающие из этого.

Если мы обратим внимание на судебную практику США, то увидим весьма неоднозначную позицию в решении одного из судов: «Публичный порядок Соединенных Штатов, который используют в качестве препятствия для действия, - это то, что провозглашено Конституцией, а именно, что частная собственность не может быть изъята без справедливой компенсации. Но ответ таков: наша Конституция, законы и политика не имеют экстратерриториального действия, кроме как относительно наших собственных граждан. Действия иностранного государства, направленные на изъятие собственности своих граждан, и особенно своих корпораций, здесь не являются предметом судебного рассмотрения. Такие граждане должны обращаться к своему правительству за любым возмещением, на которое они могут иметь право <...>» [7]. Таким образом, некоторые суды США обращают внимание на то, что иностранные граждане должны обращаться за компенсацией в суды своего государства, а не суды местонахождения имущества.

Как правило, ни судебной практикой, ни юридической доктриной стран Запада не оспаривается экстратерриториальное действие законов о национализации относительно имущества, которое в момент национализации находилось на территории государства, осуществившего национализацию, а затем было вывезено за границу в порядке ведения внешней торговли, в качестве экспонатов на выставки или для иных целей.

Раймонд Сарро в своем докладе на коллоквиуме Международной ассоциации юристов-демократов в 1957 г. отметил, что бесполезно безапелляционно заявлять, не принимая во внимание международную реакцию, о якобы общепризнанных положениях, в силу которых национализация имеет безусловный экстратерриториальный характер и у государства не возникает обязанности по возмещению ущерба, так как в международном праве нет правила, устанавливающего обязанность по адекватной компенсации [3, с. 36]. Считаем, что во второй декаде XXI века с этим нельзя согласиться, так как обязанность по адекватной компенсации должна вытекать из общего принципа права собственности, который заключается в возможности применения любого правомочия относительно блага (более расширенно см. классификацию Энтони Оноре [8]. - И. А.). Лицо не может быть принудительно лишено собственности, даже при наличии общественной необходимости. Размер адекватной компенсации должен измеряться в совокупности с такими факторами, как “состояние» собственности, ее предназначение, рыночная цена, действовавшая на момент такого изъятия у собственника. Отсутствие компенсации за принудительное изъятие собственности можно и следует сравнивать с таким явлением, как «грабеж».

Решающее значение для признания судами принципа экстратерриториального действия законов о национализации имела длительная борьба советского государства, которую оно вело за признание своих прав на имущество, приобретенное в силу законов о национализации.

Стоит вспомнить о признании судами экстратерриториального действия законов о национализации в Советском Союзе. Первым решением, которым было признано экстратерриториальное действие советских законов о национализации, было решение Высокого суда Великобритании от 12 мая 1921 г. по делу «А.М. Лютер против Д. Сегора». Суть этого известного дела сводилась к следующему. В августе 1920 г. Наркомвнешторг Российской Советской Федеративной Социалистической Республики (далее - РСФСР) продал английской фирме «Сегор» партию фанеры. До национализации фанера была собственностью акционерного общества «Лютер». Национализированный товар (фанера) в момент национализации находился на складе предприятия общества «Лютер» в Новгороде. После прибытия фанеры в Великобританию бывшие собственники общества «Лютер» предъявили иск фирме «Сегор» о возврате фанеры. Первоначально иск был удовлетворен, однако при вторичном рассмотрении дела уже после заключения первого торгового договора между РСФСР и Вели- 
кобританией в 1921 г. английский суд отклонил иск. Судья Скретон (Scrutton), в частности, указал, что если Л. Красин (глава советской торговой делегации) привез товары в Англию от имени своего правительства и объявил, что они принадлежат правительству, то ни один английский суд не может проверять такое заявление. Как заявил судья Варингтон (Warrington), суд не может «входить в рассмотрение вопроса о действительности актов, коими право собственности на спорные товары было изъято от истцов и перенесено на ответчиков». Судьи отвергли довод истца о том, что советские законы о национализации противоречат принципам справедливости и морали и поэтому действие их не может быть признано в Великобритании [9, с. 200-201].

Выводы. Экстратерриториальное действие актов о национализации основывается, в первую очередь, на принципе государственного суверенитета. С одной стороны, принцип государственного суверенитета утверждает политико-правовую самостоятельность государства и дает ему (государству) возможность исключительного верховенства государственной власти, в том числе и на отчуждение собственности. С другой стороны, принцип национализации видится как некий концепт, все-таки нарушающий священное право частной собственности.

В мировой практике сложились две доктрины, которые имеют диаметрально расходящиеся точки зрения на экстратерриториальное действие законов о национализации, а вопрос возмещения убытков целиком и полностью находится в юрисдикции конкретного государства. В связи с этим остается актуальной задача систематизации и унификации правил проведения национализации как крайней меры регулирования экономики, как на международном, так и на внутригосударственном уровне.

\section{Литература}

1. Ашихмін І. Націоналізація іноземних інвестицій як прояв принципу суверенітету держави. Політико-правова доктрина державного суверенітету в умовах глобалізації : матеріали Міжнародної науково-практичної конференції, присвяченої 100-річчю зі дня народження доктора юридичних наук, професора Л.М. Стрельцова (25.10.1918 р. - 24.03.1979 р.). Видавничий дім «Гельветика», 2018. С. 114-117.

2. Резолюция 1803 (XVII) Генеральной Ассамблеи ОOH «Неотъемлемый суверенитет над естественными ресурсами» от 14 декабря 1962 года. URL: https://zakon.rada.gov.ua/ laws/show/995_819.

3. Мингазова И. Право собственности в международном праве. Москва : Волтерс Клувер, 2007. 192 с.

4. Resolution 626 (VII) adopted by the General Assembly during its 7th session: GAOR, 7th session "Right to exploit freely natural wealth and resources". URL: https://undocs.org/en/A/RES/626(VII).

5. Резолюція 3201 (S-VI) від 1 травня 1974 р. «Декларація про встановлення нового міжнародного економічного порядку». URL: https://zakon.rada.gov.ua/laws/ show/995_339.

6. Meyzeaud-Garaud M. Droit international privé. 2-e edition. Bréal, 2008. 193 p.

7. U. S. Supreme Court Decision on case United States v. Belmont, 301 US 324, 332 (1937). URL: https://supreme. justia.com/cases/federal/us/301/324/.

8. Honore A. Ownership. Oxford essays in jurisprundence. 1961. Р. 112-128.

9. Богуславский М. Международное частное право. 5-е изд. Москва : Юристъ, 2005. 604 с.

Ашихмин И. М., аспирант кафедры международного и европейского права Национального университета «Одесская юридическая академия» 